\title{
A new species of lynx spider of the beterophthalmus group, Oxyopes iranicus sp.n. (Aranei: Oxyopidae) from Iran
}

\section{Новый вид паука-рыси из группы beterophtbalmus рода, Oxyopes iranicus sp.n. (Aranei: Oxyopidae) из Ирана}

\author{
S.L. Esyunin*, Pashaei Rad ${ }^{* *}$, M.S. Kamoneh**

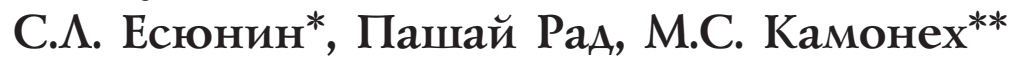

\footnotetext{
* Perm State University, Bukireva Str. 15, Perm 614990 Russia. E-mail: Sergei.Esyunin@psu.ru

** Department of Zoology, Faculty of Biological Science, Shahid Beheshti University, G.C. Tehran Iran. E-mail: mahsak30@gmail.com

* Пермский государственный университет, ул. Букирева 15, Пермь 614990 Россия.

** Кафедра зоологии, Факультет биологии, Университет им. Шафида Бехешти, Тегеран Иран.
}

KEY WORDS: Spider, Oxyopes, new species, Iran.

КЛЮЧЕВЫЕ СЛОВА: Пауки, Oxyopes, новый вид, Иран.

ABSTRACT. A new species of lynx spider, Oxyopes iranicus sp.n. $\left(O^{7} O\right)$, from the heterophthalmus species group is described from Iran.

РЕЗЮМЕ. Новый вид пауков-рысей Oxyopes iranicus sp.n. $\left(\sigma^{7}\right.$ ) $)$ из группы heterophthalmus описан из Ирана.

\section{Introduction}

Oxyopes Latreille, 1804, with the Aranea heterophtalma Latreille, 1804 as the type species, is the largest genus of the lynx spiders (Oxyopidae) comprising 293 species [Platnick, 2010]. In its modern treatment [see Levy, 1999: 34], the genus seems to be a paraphyletic taxon and consists of the species groups significantly differing in their structure of the copulatory organs. In his revision of the North American Oxyopidae, Brady [1964] distinguished two species groups of Oxyopes, the acleistus and apollo groups, to which most species were attributed. In addition, Brady assumed that additional groups should be established for O. salticus Hentz, 1845, and O. scalaris Hentz, 1845.

The heterophthalmus group has recently been redefined by Esyunin \& Tuneva [2009] to include only the three Palaearctic species: viz., O. heterophthalmus (Latreille, 1804), O. nenilini Esyunin et Tuneva, 2009, and O. takobius Andreeva et Tystshenko, 1969. This group can be characterized by the following two characters:

(1) The lateral process of the palpal tibia consists of 2 parts: the short basal part, forming the right angle with the segment's axis, and the apical, large and lamellar part, with an additional needle-shaped process at its apex. The apical lamellar part is usually broken during copulation and is left under the epigynal plate of the female; this is the reason this structure is also known as a "separated part of the lateral processes of the palpal tibia". After copulation, the male palp does not have this structure, which makes identification of males of the heterophthalmus group difficult or impossible because of the great variation of body coloration and similarity in other sclerites of male palps [Esyunin \& Tuneva, 2009];

(2) The epigyne possesses a wide chitinized central plate situated immediately in front of the epigastric furrow and pointed anteriad. The copulatory ducts are long, twisting three times around the receptacle. While describing or diagnosing Oxyopes species from the heterophthalmus group, a priority should be given to the mated females. In this case, both the female copulatory organs and the broken apical part of the lateral palpal process of the conspecific males can be examined, allowing a full taxonomic characterstics of the species even in the absence of the male specimen.

In the newly collected spider material from Iran, we have found two species of Oxyopes: O. lineatus Latreille, 1806, which was already recorded from Iran [see Mozaffarian \& Marusik, 2001], and a new species belonging to the heterophthalmus group. As the male specimen is in poor condition (it is dried up and strongly shrunk), we have selected the mated female as the holotype which is in good condition and retains its colour pattern. Besides, the separated part of lateral processes of male palpal tibia has been removed from under the epigynal plate and examined. The types are deposited in the collection of the Zoological Museum of Moscow State University, Moscow, Russia (curator: K.G. Mikhailov). 

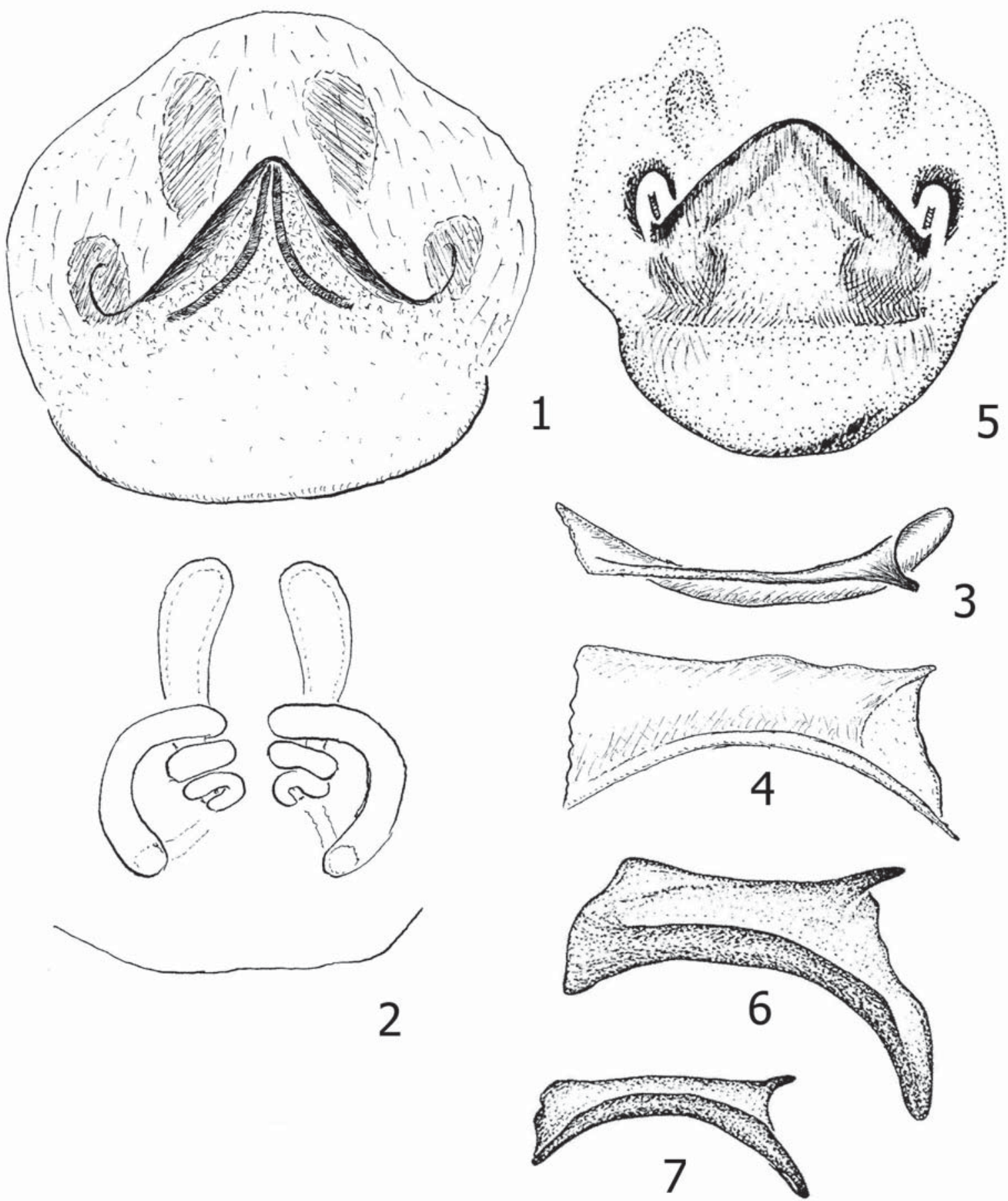

Figs 1-7. Oxyopes iranicus sp.n. (1-4), O. nenilini Esyunin et Tuneva, $2009(5,6)$ and $O$. heterophthalmus (Latreille, 1804) (7): 1, 5 - epigyne, 2 - endogyne, 3 - separated part of lateral processes of palpal tibia of male, dorsal view; 4, 6, 7 - same, lateral view (5, 6 and 7 after Esyunin \& Tuneva [2009]).

Рис. 1-7. Oxyopes iranicus sp.n. (1-4), O. nenilini Esyunin et Tuneva, 2009 (5, 6) и O. heterophthalmus (Latreille, 1804) (7): 1, 5 эпигина, 2 - эндогина, 3 - отделяющаяся часть латерального отростка голени пальпа самца, сверху, 4, 6, 7 — то же, сбоку $(5,6$ и 7 по Есюнин \& Тунева [2009]). 


\section{Taxonomic part}

Oxyopes iranicus sp.n.

Figs. 1-4.

MATERIAL. Holotype + , Iran, nr. Hamedan City, Dare Morad Beig Vil. ( $\left.34^{\circ} 44^{\prime} \mathrm{N}, 48^{\circ} 27^{\prime} \mathrm{W}\right), 2310 \mathrm{~m}$ a.s.l., in grass, 12.VI.2010, M.S. Kamoneh. Paratypes: $1 \sigma^{2}, 1$, together with the holotype.

DESCRIPTION. Female (holotype). Total length 8.7. Carapace length 3.7, width 2.5. Clypeus length 1.0. Chelicera length 1.5 . Ocular area length 0.8 , width 1.2. Cheliceral furrow with 1 small tooth on anterior margin and 1 anterior tooth at posterior margin. Spination of leg femora: I-III: pl 0-1-1, d 1-1-1, rl 0-1-1; IV: pl 0-1-1, d 1-1-1, rl 0-0-1. Leg index: I-II-IV-III; measurements of leg segments are given in the table:

\begin{tabular}{|l|c|c|c|c|c|}
\hline & Femur & $\begin{array}{c}\text { Patella+ } \\
\text { Tibia }\end{array}$ & Metatarsus & Tarsus & Total \\
\hline Leg I & 3.4 & 4.8 & 3.6 & 1.1 & 12.9 \\
\hline Leg II & 3.5 & 4.3 & 3.4 & 1.3 & 12.4 \\
\hline Leg III & 2.9 & 3.4 & 2.7 & 1.0 & 9.9 \\
\hline Leg IV & 3.3 & 3.9 & 3.4 & 0.9 & 11.5 \\
\hline
\end{tabular}

Carapace ( $q$ paratype): light brown (sand-colour); thoracic section with a pair of white longitudinal median spots connected posteriorly, and with a white edging and pair of lateral spots between the lateral stripe and the ocular field; the clypeus with a pair dark patches; the area above labium white. Sternum brown, with yellow median spot, dark long setae and white hairs, and with a narrow longitudinal spot extending along the entire length of sternum. Maxillae yellow. Labium black, with yellow apex. Legs yellow, with dorsal grey longitudinal stripes. Abdomen: dorsum with a grey lanceolate spot and a white longitudinal median stripe; venter grey in the middle, with white longitudinal stripes at each side; colliculi brown. Epigyne with the triangular central plate pointed anteriad (Fig. 1); the epigynal plate brown, with dark brown lateral margins and longitudinal stripes joining anteriorly. The spermathecae as in Fig. 2.

Male (dried and in poor condition). Total length 6.7. Carapace length 3.7, width 2.6. Carapace and leg femora with white hairs. Spination of leg femora as in the female. Abdomen pattern as in the female, but colouration blackish. Cymbium brown. Structure of the palp is typical for the group [e.g., see Roberts, 1985: fig. 55a; Levy, 1999: figs 2A-B]; the separated part of lateral processes of palpal tibia with a small upper branch and a downward-curved lower branch (Fig. 4).

DIAGNOSIS. The female of the new species is very close to that of $O$. nenilini Esyunin et Tuneva, 2009 , but differs in shape of the epigynal plate (cf. Figs 1 and 5). The male of $O$. iranicus sp.n. is close to those of $O$. nenilini and $O$. heterophthalmus, but differs in the shape of separated part of lateral processes (cf. Figs 4 and 6,7$)$.

ETYMOLOGY. The specific epithet is after the type locality, Iran.

DISTRIBUTION. Known from the type locality only.

ACKNOWLEDGEMENTS. This project was funded by the Russian Foundation for Basic Research (grants \#\# 0904-01365-a; 11-04-01716-a) and through a grant of the President of the Russian Federation for the support of leading scientific schools.

\section{References}

Brady A.R. 1964. The lynx spiders of North America, North of Mexico (Araneae: Oxyopidae) // Bull. Mus. Comp. Zool. Vol.131. No.13. P.429-518.

Esyunin S.L., Tuneva. T.K. 2009. A Review of Palaearctic LynxSpiders of the Oxyopes heterophthalmus Group (Aranei, Oxyopidae) // Zool. zhurn. Vol.88. No.2. P.164-175 [in Russian; Ent. Review. 2009. Vol.89. No.1. P.99-110 in English].

Levy G. 1999. The lynx and nursery-web spider families in Israel (Araneae, Oxyopidae and Pisauridae) // Zoosystema. Vol.21. No.1. P.29-64.

Mozaffarian F., Marusik Yu.M. 2001. A checklist of Iranian spiders (Aranei) // Artropoda Selecta. Vol.10. No.1. P.67-74.

Platnick N.I. 2010. The World Spider Catalog, Version 10.5. American Museum of Natural History. New York. Online at http:// research.amnh.org/iz.spiders/catalog/

Roberts M.J. 1985. The spiders of Great Britain and Ireland. Part 1. Colchester: Harley Books Press. 229 p.

Responsible editor D.V. Logunov 